\title{
Kriminálpszichológia és kriminálpszichológus
}

\section{VILICS Tünde ${ }^{1}$}

\begin{abstract}
A Magyar Pszichológiai Társaság keretein belül a kriminálpszichológia önálló tagozatot alkot (Kriminálpszichológiai és Igazságügyi Pszichológiai Szekció), noha a szakirány speciális képzéssel nem rendelkezik, így kriminálpszichológusi képesítéshez sem juttat. ${ }^{2}$ Kriminálpszichológusokkal találkozhatunk a hatóság bünüldöző munkájának, az igazságszolgáltatás múködésének keretein belül, a büntetés-végrehajtás során, valamint az áldozatvédelem területén is. ${ }^{3}$ Felmerülhet akkor a kérdés: kik is a kriminálpszichológusok, milyen feladatokat látnak el, és milyen kompetenciákkal kell rendelkezniük?

E tanulmány célja, hogy a kriminálpszichológia egyes, eddig sürün alkalmazott és kevésbé ismert feladategységeit, valamint azok gyakorlati jelentőségét összefoglalja, párhuzamosan bemutatva az alkalmazó szakember kompetenciaterületeit, ezzel javaslatot téve egy szakirányú képzés kialakítására.
\end{abstract}

Kulcsszavak: kriminálpszichológia, rendőrség, hazugságvizsgálat, személyiségjegyek, kompetenciák, oktatás

\section{A kriminálpszichológia és a „kriminális személyiségzavar”}

\subsection{A kriminálpszichológia területe}

„A kriminálpszichológia olyan alkalmazott lélektani szakágazat, amely a bünelkövető, a bűncselekmény és a bűnözés elleni harc (megelőzés, bűnüldözés, büntetés-végrehajtás és rehabilitáció, illetve utógondozás) pszichológiai kérdéseivel foglalkozik."4 Ez a terület elsősorban az ép tudatállapotú, beszámítható személyeket helyezi górcső alá, azaz feltételezi, hogy a bűnelkövetés nem a társadalmi normák megértésének és tanúsításának képességbeli hiányából ered, hanem azok könnyelmü kezeléséből vagy szándékos áthágásából. ${ }^{5}$ Emellett, bizonyos mértékig, a nem beszámítható vagy korlátozott beszámítási képességgel rendelkező személyekkel is dolgozik (például az Igazságügyi Megfigyelő és Elmegyógyító Intézetben vagy az igazságügyi pszichológus szakértői

\footnotetext{
VILICS Tünde, r. főhadnagy, klinikai szakpszichológus, alapellátó pszichológus, Budapesti Rendőr-főkapitányság Tünde VILICS, lieutenant, clinical psychologist in the primary care system of the Budapest Police Headquarters https://orcid.org/0000-0001-9809-4890; vilicst@budapest.police.hu

2 Boros János: Jogpszichológia és kriminálpszichológia. Belügyi Szemle, 52. (2004), 6. 5-19.

3 Pásztor Attila - Mityók Csaba - Németh Ferenc: A rendvédelmi bünügyi pszichológiai tevékenység szakmai protokollja.

4 Popper Péter: Kriminálpszichológia. In Viant Katalin - Palcsó Mária (szerk.): A rejtőzködő lélek keresése. Budapest, Saxum, 2007. 321-375.
}

5 Uo. 
vizsgálatok során), ugyanakkor hangsúlyozandó, hogy a beszámítási képesség megállapítása, az arról való döntés igazságügyi (orvos) pszichiáteri kompetencia. ${ }^{6}$ Továbbá érdemes szem előtt tartani, hogy a beszámíthatóság állapota nem feltételez mentális egészséget, sőt, börtönpszichológiai kutatások szerint a legtöbb elítélt valamilyen személyiségzavarral, pszichopatológiával rendelkezik. ${ }^{7}$

A kriminálpszichológia három ága bemutatja a tudományterület komplexitását. 1. A kriminológiai pszichológia a bűnözés, bűnözővé válás társadalmi és egyéni pszichológiai hátterével foglalkozik, megkülönböztetve a krízis- (eseti) és krónikus (életmódszerű) bűnözőket (meghatározva ezzel a prevenció irányait is: a tett vagy a személyiség antiszociális jellegére reagálva). 2. A kriminalisztikai pszichológia a bűnüldözés jogi intézkedéseivel járó pszichés hatásokat, körülményeket vizsgálja (vallomások, nyomozási és bizonyítási cselekmények pszichológiai szempontú elemzése, tényállásdiagnosztika). 3. A reszocializálás pszichológiája (vagy börtönpszichológia) pedig a társadalomba való visszaillesztés pszichés vonatkozásaival, ezen belül a börtön személyiséget deformáló, „prizonizáló” hatásával is foglalkozik. ${ }^{8}$ Mindebből következik, hogy a kriminálpszichológia a pszichológia tudományán kívül még számos más stúdium anyagát is tartalmazza (orvosi, antropológiai, szociológiai, jogi és rendészettudományi ismeretek).

\subsection{A bünelkövetéssel összefüggö személyiségjellemzök}

A bűnelkövető személy sajátos vonásai három pontban összefoglalhatók. 1. Általános, személyiségbeli éretlenség, amely fejlődésbeni elakadás eredménye (feszültségteli helyzetek rossz toleranciája, késleltetés és a kitartás képtelensége, ingerkereső tevékenység, fokozott jelenidejűség és énközpontúság, csökkent vagy hiányzó empátiás készség, tettek következményeinek figyelmen kívül hagyása, ösztönkiélési formák elsődlegessége, ellentétes szociális szerepek egyidejü gyakorlása). ${ }^{9}$ 2. Morális defektus, grandiózus-én (a hiányzó vagy torz erkölcsi normák hátterében a düh, hiány vagy feljogosítottság érzése lappang, ami az én-funkció és az önértékelés zavarában mutatkozik meg, amely állapotban a bűncselekmény véghezvitele egy túlkompenzálási kísérlet a csökkentértékűség érzésével szemben). ${ }^{10} 3$. Az agressziv telitettség magas foka és annak társadalmilag elfogadhatatlan megoldási módjai (létrejön, amikor a gyermeknél tapasztalható, a környezet felfedezésére irányuló agresszív viselkedés nem kerül a társadalmi normáknak megfelelő szülői kontroll alá, így később oppozíciós viselkedésben rögzül) $)^{11}$.

13/2014. (XII. 16.) IM rendelet a kényszergyógykezelés és az ideiglenes kényszergyógykezelés végrehajtásáról, valamint az Igazságügyi Megfigyelő és Elmegyógyító Intézet feladatairól.

Boros János - Csetneky László: Börtönpszichológia. Budapest, Rejtjel, 2002.

Popper (2007) i. m.

Uo.

Alfred Adler: Életünk jelentése. Budapest, Kossuth, 1994.; Alfred Adler: Emberismeret. Budapest, Göncöl, 1996.

Popper Péter: A kriminális személyiségzavar kialakulása. Budapest, Akadémiai Kiadó, 1970. 
A tiszteleten alapuló kapcsolatok és az önreflexiós folyamatok defektusa, valamint a bűnözőkre jellemző egocentrikus gondolkodásmód hátterében a biztonságos szülőgyerek kötődés hiánya áll, amely a társadalmi együttéléshez nem fejleszt ki elegendő alkalmazkodási képességet. Elkényeztető, elhanyagoló és/vagy bántalmazó gondozása miatt a későbbi bűnöző már gyermekkorában képtelen lesz saját szükségleteitől, vágyaitól elvonatkoztatni, másokat figyelembe venni. Nem tud megnevezni általa tisztelt személyeket (hiszen a szülő sem tudott azzá válni); vagy a respektábilis személy antiszociális magatartása mintaképpen szolgál számára. ${ }^{12} \mathrm{~A}$ „túlszeretett” gyerek megmarad az infantilis érzelmi kötődés állapotában, amit felnővén már csak a szülő felé tud eredményesen használni, emiatt az élet minden más területén csalódások érik. Szocializálódása sikertelen marad (amely kudarc csak agresszióját fokozza), hiszen a szülői, mindent megengedő és alkalmazkodást nem követelő közeghez képest minden más légkört ridegnek és félelemtelinek tart. Az elhanyagolás pedig, megzavarja a szülővel való azonosulás folyamatát, így a felnőtt szerepek elsajátítását, sőt, azokat nemkívánatossá teszi, szintén konfliktusokat eredményezve a társadalmi szférában. ${ }^{13}$ Mindezek gátolják a személyt az eredményes beilleszkedésben és a felelősségteljes felnőtt lét kialakításában. ${ }^{14}$

Fentebbiekből következik, hogy a bűnelkövető személyekkel történő eredményes pszichológusi munkához az illető élettörténetének, az őt ért maladaptív nevelési formák hatásainak és a fejlődéslélektannak az ismerete elengedhetetlen. Tisztában kell lenni továbbá az egyes személyiségzavarok jellemzőivel, a nonverbális kommunikációs sajátosságokkal, valamint a pszichodiagnosztikai eszközök használatának és értékelésének szabályaival, a nyert információkból pedig következtetni kell tudni az egyén morális és intellektuális szintjére. Mindez utóbbi már klinikai és mentálhigiéniai szakpszichológusi végzettséget és kriminológiai ismereteket is igényel.

\section{A pszichológus helye a kriminálpszichológiában, feladatkörök és szükséges kompetenciák}

A „klasszikus kriminálpszichológiai munka” olyan eljárásokat takar, amelyek a bűnüldöző munkát segítik. Ezek alapvetően öt nagy területre oszthatók: társításos aszszociációs módszerek; emlékezetvizsgálatok; pszichofiziológiai módszerek; hipnózis; személyiségvizsgálatok ${ }^{15}$. Ezek a módszerek ma már nem fednek le minden, a kriminálpszichológia területén használatos pszichológiai tevékenységet (például börtönpszichológia vagy áldozatvédelem). Jelenleg legtöbbjük egyetemi vagy emellett egy

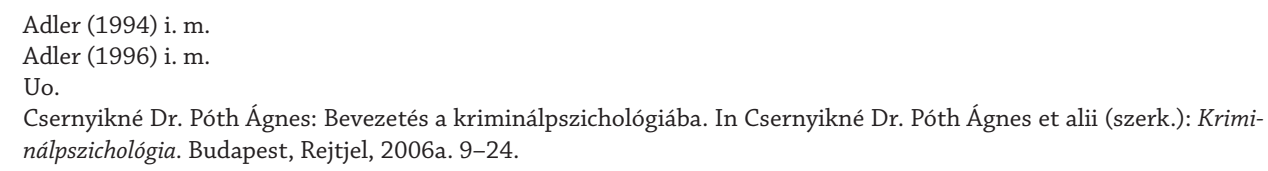


módszertani (hipnózis) ${ }^{16}$ végzettséggel ellátható, a személyiségvizsgálatok (vagy pszichodiagnosztika) kivételével, amely (a pszichiátriai betegségek kiszűrése okán - ami nem a beszámíthatóságot vizsgálja, hanem az egyes kórképek fennállási lehetőségeit) klinikai szakpszichológusi kompetenciát követel. A következőkben bemutatjuk, hogy napjainkban a rendvédelem mely területein vesznek igénybe pszichológusi munkát.

\subsection{Kihallgatás}

A kihallgatás (vagy gyermekek esetében meghallgatás) a büntetőjogilag releváns tények beszerzése céljából végrehajtott nyomozati cselekmény és egyben a legalapvetőbb kriminálpszichológiai eszköz is, amelyben vizsgálandó a kihallgatott személy és a nyomozó magatartásának egymásra hatása is. ${ }^{17} \mathrm{~A}$ hatóságot képviselő személy kifogásolható, domináló, flegmatikus, utasító, fenyegető stb.) viselkedése esetén a meghallgatott téves, hamis, torzított információkat fog megosztani, vagy azok ismertetését vissza fogja tartani (ellenáll). Mindemellett az is várható, hogy a bűnelkövető/tanú szándékosan hazudni fog. ${ }^{18} \mathrm{~A}$ motivációs háttér megismerése segít az átélt stresszhelyzetek értelmezésében, a befolyásoltság kiderítésében és a társadalmi veszélyességi fok megítélésében. A kihallgatást befolyásoló hatások (amelyet akár krízishelyzetként is megélhet az eljárás alá vont személy) ${ }^{19}$ és a megtévesztő jelek kiszűrése céljából egyre többet alkalmaznak pszichológusokat. ${ }^{20}$

A személyiségjellemzők megismerésén túl, kiemelkedő szempont a biológiai tényezők szerepének és az egyén élménymegélési stílusának (érdeklődési körének) vizsgálata. ${ }^{21}$ Előbbi azért mérvadó, mert vannak olyan pszichiátriai betegségek, amelyek genetikai alapon szerveződnek, öröklődhetnek, és noha még a bűnelkövetés útját nem garantálják, de deviáns környezetben manifesztálódva könnyen eredményezhetnek búnözői életutat (például a skizofréna, a hiperaktivitás és figyelemzavar vagy az értelmi fogyatékosság bizonyos típusai). ${ }^{22} \mathrm{Az}$ élménymegélés milyensége pedig lényegében egyfajta életstílus-elemzés, ${ }^{23}$ ami választ adhat arra, hogy különböző életeseményekre az alany miképpen reagálhat, toleranciája meddig terjedhet.

\footnotetext{
16 Ezek közül a hipnózis mint külön módszer a magyar bủnüldözésben nem használatos. (Lényege, hogy speciális mentális gyakorlat révén az alany egy jelen tudtaállapotától eltérő észlelési szintre kerül, ahol a gátlások feloldódnak, így akár olyan információkhoz is hozzá tud jutni a vizsgáló, amelyek nem csak elhallgatás során vesznének el. Használata azonban etikátlan lehet a nyomozásban, hiszen más, nem az elkövetéshez tartozó információkkal nem hagyható magára a vizsgált személy. Emiatt terápia része.)

17 Kertész Imre: A kihallgatási taktika lélektani alapjai. Budapest, Közgazdasági és Jogi Könyvkiadó, 1965.

18 Csernyikné Dr. Póth Âgnes: A kihallgatás pszichológiája. In Csernyikné Dr. Póth Ágnes et alii (szerk.): Kriminálpszichológia. Budapest, Rejtjel, 2006b. 171-212.

19 Popper (2007) i. m.

20 Nagy Vanda: Hazudj, ha tudsz - pszichológus szemmel. 2016.

21 Kertész (1965) i. m.

22 Bereczkei Tamás: Genetikai és evolúciós tényezők a deviáns és a bünözői viselkedés kialakulásában. Belügyi Szemle, 47. (2004), 6. 21-33.

23 Adler (1996) i. m.
} 
A kihallgatás során a pszichológus által végzett „személyiségvizsgálatok” felmérhetik a személy érzékelés-lélektani sajátosságait (látás, hallás, tapintás, szaglás, ízlelés), észlelési elemeit (távolság, térnagyság, idő, beszéd, figyelem), memóriaműködését (emlékanyag-bevésés, megtartás, felejtés, felidézés), valamint kognitív sajátosságait (gondolkodási minták, sémák, hibák, túlzások). ${ }^{24}$ Eredményei jelzést adnak a gondatlanság és a pszichiátriai érintettség kérdésére - amely információk ítéletet meghatározóak. Az anamnesztikus jellegú alaposabb interjú nemcsak az ügyre, de a személyre is szenzitív információk, témák érintésével kedvezően befolyásolhatja a meghallgatott viselkedését, együttmúködését. Fentebbi szempontokból következik az elemzést végző pszichológus klinikai tapasztalatának igénye.

\subsection{Túsztárgyalás, válságkezelés}

A kriminálpszichológia sajátos fegyelmezettséget és gyakorlatot igénylő feladatköre a túsztárgyalás, amely kommunikációs eszközök tudatos használatára épülő krízisintervenciós tevékenység. A szituáció sajátossága a fokozott stresszhelyzet. A döntéseket és az azokra épülő akciókat haladéktalanul meg kell ejteni, mérlegelésre kevés idő áll rendelkezésre. A túszhelyzet kiemelt figyelmet érdemlő esemény, minden olyan bűncselekmény idetartozik, ahol ártatlan személyek sérülést szenvedhetnek vagy életveszélybe kerülhetnek, függetlenül attól, hogy mozgásukat korlátozzák-e, vagy sem. ${ }^{25}$ Hasonló tárgyalási technikát alkalmaznak kóros elmeállapotú személy megfékezésénél, illetve öngyilkossági szándék megakadályozásánál is. ${ }^{26}$

A túszejtők viselkedésük alapján különféleképpen tipizálhatók, ${ }^{27}$ amelyek leírásaiban megtalálhatjuk a személyiségzavarok pszichiátriai diagnosztikai kritériumait is; ${ }^{28}$ ennek mentén az „ôrült” túszejtő borderline és skizotip; a „bűnözô" antiszociális és pszichopata; a „fanatikus” pedig nárcisztikus és hisztrionikus jegyekkel rendelkezik. Ezeket felismervén reakciójuk és viselkedésük nagyobb biztonsággal bejósolható és könynyebben választható meg a hozzájuk illő tárgyalási mód. Talán ennél is nehezebb feladat az úgynevezett Stockholm-szindróma kezelése (amikor a túszejtő és a túsz között pozitív töltésű érzelmi kapcsolat alakul ki), amikor a sikeres akciót a túszejtő és a túsz érzelmi egymásra hatása is befolyásolja. ${ }^{29}$

A sikeres eljárás elsősorban csapatmunkára, szabálykövetésre, fegyelemre, rugalmasságra és magas szintű szakmai felkészültségre épül, úgy a közremúködő

\footnotetext{
24 Kertész (1965) i. m.

25 A Büntető törvénykönyvről szóló 2012. évi C. törvény szerint: terrorcselekmény (324. §), légi jármű hatalomba kerítése (320. §), emberrablás (190. §), szökés (434. §), fogolyzendülés (284. §), közveszélyokozás (322. §), robbanóanyaggal vagy robbanószerrel visszaélés (324. §), lőfegyverrel visszaélés (325. §), radioaktív anyaggal visszaélés (250. §), családi állás megváltoztatása (213. §), kiskorú elhelyezésének megváltoztatása (211. §).

26 Győrffy Ágnes: A túsztárgyalás pszichológiája. Belügyi Szemle, 52. (2004), 6. 66-80.

27 Uo. 68-70.

28 DSM-5 referencia-kézikönyv a DSM-5 diagnosztikai kritériumaihoz. Budapest, American Psychiatric Association - Oriold és Társai Kiadó, 2015.

29 Győrffy (2004) i. m.
} 
pszichológus, mint az eljáró tisztek részéről. A túsztárgyalásban részt vevő pszichológus tapasztalt kell hogy legyen az egyes pszichiátriai kórképeket és az eredményes kezelésükhöz alkalmazandó speciális kommunikációt illetően is (tehát a klinikumban és rendvédelemben szerzett tapasztalatok szükségesnek bizonyulnak). Végül a túsztárgyalás a tárgyaló felek számára is krízishelyzet lehet, ami erős stressz- és bizonytalanságtűrést követel meg.

\subsection{Profilalkotás}

A profilalkotás alapvetően statisztikai alapú, bủnügyi elemző, értékelő, rendszerező tevékenységet jelent, amely során a bűncselekmény helyszínén található nyomok, bűnjelek pszichológiai, pszichiátriai (pszichopatológiai, szociológiai) szempontú összegzése történik meg. ${ }^{30}$ Célja, hogy az adatok alapján következtetést nyerjen az ismeretlen elkövető személyisége, attitűdje, egyes testi jellemzői (például kezesség), neme, kora, alkata vagy társadalmi csoporthoz való hovatartozása. Az elemzés lehetőséget ad továbbá az elkövetés motivációjának és indokának feltárására is. ${ }^{31} \mathrm{E}$ szempontok mentén már számos elkövetői csoportosítás készült, ${ }^{32}$ amelyek jellemzői mind komoly pszichiátriai kórképek fennállását is mutatják (például a hiányos szociális készségek, a folyamatos foglalkoztatottság hiánya, a szexuális éretlenség; az intelligencia alacsonyabb szintje és az elkövető szerény iskolázottsága). Ezek utalnak a tettes igényszintjére, életmódjára és viselkedésére (például képes-e átgondolt cselekmény végrehajtására, elrejti-e a holttestet és a bizonyítékokat, nyomon követi-e a későbbi sajtóhíreket, stb.). Az agresszív cselekmények és a kommunikáció minősége (domináns, manipulatív) a pszichopátia azonosításában elsődleges szempontok. Más jelekből pedig a szorongásszint állapítható meg (például a lakhely és állás megváltoztatása, az áldozatok jelleg szerinti vagy véletlenszerű kiválasztása). Végül mindez utal az elkövető kultúrájára, nevelésére, családban betöltött szerepére, helyzetére, amelyek elsősorban a bűnjelek közötti, sokszor nem manifeszt összefüggések mentén deríthetők ki.

A hatékony profilalkotáshoz a szakembernek szükséges lehet a bünügyekben (eljárás alatti viselkedés), a börtönben (elítéltek élettörténetei) és a klinikumban (pszichiátriai betegek jellemzői) szerzett tudás és tapasztalat. Emellett érdemes lehet a pszichológust a helyszíni szemle munkájába is bevonni, környezetpszichológiai szempontú elemzés céljából.

\footnotetext{
30 Lehoczki Ágnes: Nehézségek és módszertani dilemmák a profilalkotás hazai kutatásában. Magyar Rendészet, (2014), 2. 51-61.

31 Brian Innes: Bünös elmék. Budapest, Skandi-Wald, 2003.

32 Csernyikné Dr. Póth Ágnes: A profilalkotás lényege. In Csernyikné Dr. Póth Ágnes et alii (szerk.): Kriminálpszichológia. Budapest, Rejtjel, 2006c. 213-217.
} 


\subsection{Igazságügyi szakértôii tevékenység}

Az igazságügyi szakértôi tevékenység egy meghatározott, hatósági döntéshez szükséges, személyiségjegyeket érintő szakkérdés megválaszolását jelenti. Nem keverendő össze a pszichiáterek kompetenciakörébe tartozó elmeorvosi vizsgálattal, amely a tudatállapot minőségét méri fel (beszámíthatóság kérdése). ${ }^{33} \mathrm{Az}$ igazságügyi pszichológia az egészséges és az egészségestől eltérő mentális müködés, személyiségvonások, képességnormák és nevelési hatások vizsgálatát végzi. Segít megállapítani a bûncselekmény megvalósulásának tényét, az ahhoz vezető kockázati faktorokat, a gyermek befolyásolásának vagy bántalmazásának fennállását/hiányát, a nevelési alkalmasságot (válás, gyermekelhelyezés ügyében), valamint a konfliktusos családi múködés (gyermeki) személyiségét érintő következményeit (polgári és büntetőügyekben, valamint gyámhivatali eljárásokban egyaránt). ${ }^{34} \mathrm{~A}$ pszichológusi szakértői vélemény további szakorvosi vizsgálathoz és kényszergyógykezelés elrendeléséhez adhat alapot. ${ }^{35} \mathrm{~A}$ szakértő nyilatkozik a vizsgált személy élményszerủ (hitelességet meghatározó) előadásmódjáról, amely nem más, mint „az élménybeszámolók hátterében múködő lélektani folyamatok jellegének, minőségének feltárása, leírása, értékelése, az adott élmények adekvát átélése, az átélésről komponált, illetve instruált közlés, konfabuláció, az élménybeszámoló adekvációs fokába ágyazott elhihetőség megállapítása", ${ }^{36}$ a megtévesztő magatartás és a befolyásoltság felmérése. ${ }^{37}$

A gyermek meghallgatása még körültekintőbb szakértői munkát igényel. Az egyes büntényekben érintett gyermekek esetében, tisztában kell lenni a gyermek korából eredő érési, személyiségmúködésüket meghatározó sajátosságaikkal, valamint családi életük jellegzetességeivel is. ${ }^{38}$ Ennek mentén vizsgálni kell, hogy a gyermek nem szenved-e elhanyagolástól, bántalmazástól vagy netán szexuális zaklatástól. Számtalan esetben családon belül történik a büncselekmény, amely a gyermek ambivalens érzései miatt (szereti, de egyben gyúlöli is a bántalmazó/bűnöző családtagot) nehezebben feltárható. ${ }^{39}$ Kisgyermekkorban a gyermek fantáziája a valóság erejével képes múködni, ${ }^{40}$ amely a búncselekményről való érdemi kommunikációt és a megtévesztő jelek kiszűrését akadályozza (vélt, elgondolt eseményeket valóságosnak élhetnek meg). Emiatt ügyelni szükséges a körültekintő kapcsolatteremtésre. A célirányos, rendőri

\footnotetext{
Popper (2007) i. m.

34 31/2008. (XII. 31.) IRM rendelet az igazságügyi szakértői müködésről.

35 Kováts Daniella: Elmebetegségek és személyiségzavarok a bű́ncselekmények hátterében. Igazságügyi pszichiátria. In Csernyikné Dr. Póth Ágnes et alii (szerk.): Kriminálpszichológia. Budapest, Rejtjel, 2006. 116-142.

36 Az Országos Igazságügyi Orvostani Intézet 20. számú módszertani levele: Az igazságügyi pszichológus szakértôk múködési körérôl és tevékenységérôl.

37 Elek Balázs: A vallomás befolyásolása a büntetôeljárásban. Debrecen, Tóth Könyvkereskedés és Kiadó Kft., 2007.

38 Conference about the question of Domestic Violence 2018. European Association of Police Colleges. Azerbaijan, Annual Conference and Governing Board Meeting, Baku. 2018. 09. 18-19.

39 Révész György: Szülôi bánásmód - gyermekbántalmazás. Budapest, Új Mandátum, 2004.

40 Bernáth László - Solymosi Katalin (szerk.): Fejlódéslélektani olvasókönyv. Budapest, Tertia, 2001.
} 
dominanciával múködő klasszikus kihallgatási helyzeteket kerülni érdemes, a gyermeket megrémisztik vagy provokálják, az érdemi kommunikációját gátolják. ${ }^{41}$

A (gyermek)pszichiátriai kórképek viselkedést befolyásoló jellegzetességeinek ismerete elengedhetetlen a hatékony kriminálpszichológiai munkához. A büntetőeljárásról szóló 2017. évi XC. törvény 87. § (1) b) pontja szerint: „A bíróság, az ügyészség és a nyomozó hatóság a tizennyolcadik életévét be nem töltött személy részvételét igénylő eljárási cselekmény esetén elrendelheti, hogy az eljárási cselekményen igazságügyi pszichológus szakértő is jelen legyen."

Az igazságügyi szakértői képesítéshez az 5 éves pszichológiai egyetemi tanulmányokon túl 4 év klinikai szakpszichológusi képzés, majd az arra épülő 2 éves igazságügyi szakértői stúdium elvégzése szükséges, folyamatos szakirányú gyakorlat és a kötelező jogi ismeretek szinten tartása mellett. A tevékenység végzésére hatóság rendeli ki a szakértőt, a vonatkozó törvényben meghatározott függetlenség és pártatlanság követelményeinek megtartása céljából; akinek szakvéleménye kétséget kizáró bizonyítékként ítéletet befolyásoló erejű eszköz. ${ }^{42}$

\section{5. Írásszakértés, grafológia}

$\mathrm{Az}$ írásszakértés és a grafológia két külön tudományág. ${ }^{43} \mathrm{Az}$ írásszakértés olyan szakértői munka, amely során a bűnügyhöz kapcsolódó írásos anyagokból, tartalmi, személyi és tárgyi vonatkozású információk nyerhetők ki. Mivel az írás elsősorban idegrendszeri tanulási folyamat eredménye, számos személyiségjegyet hordoz magában, amely nemcsak az írásjelek egyediségében, de a szavak, szóközök, vonalvezetés, margók, bekezdések stb. és egyéb, írással összefüggő eszközök használatában is megjelenik. Az írásformából, esztétikumból, formai igényből és a használt eszközök minőségéből az író személyiségére, intelligenciájára, nemzetiségére, de az irat készítésének körülményeire is következtethetünk. ${ }^{44}$ A grafometriai elemzés az irat mérhető elemeit vizsgálja (betűk, szavak, térközök, sorközök stb.), továbbá az író szubjektív világát és pszichikumát is megpróbálják a dokumentum sajátosságából feltárni (ennek tartalomelemzés is a része). A bünjelként kezelt iratot igény esetén összehasonlítják más írásokkal, valamint - a genetikai meghatározottság miatt - a családtagoktól, rokonoktól sokszor írásmintákat vesznek (a tévedések elkerülését megelőzendően). ${ }^{45}$

\footnotetext{
41 Sue D. Hobbs et alii: Evaluating eyewitness testimony of children. In Irving B. Weiner - Randy K. Otto (ed.): The Handbook of Forensic Psychology. Hoboken, Wiley, 2014. 561-598.

42 2016. évi XXIX. törvény az igazságügyi szakértőkről.

43 Székesi István - Katona Ágnes: Az írásszakértés elmélete és gyakorlata. Eger, Országos Írásszakértő Intézet Kft., 2005.

44 Hautzinger Zoltán: Az igazságügyi kézírásvizsgálat. In Korinek László - Kőhalmi László - Herke Csongor (szerk.): Emlékkönyv Ferencz Zoltán egyetemi adjunktus halálának 20. évfordulójára. Pécs, Studia iuridica auctoritate Universitatis Pécs Publicata; Pécsi Tudományegyetem, Állam- és Jogtudományi Kar. 2004a. 93-100.

45 Vigh András: Az igazságügyi kézirásvizsgálatok aktuális kérdései. Doktori értekezés. Budapest, Eötvös Loránd Tudományegyetem, 2007.
} 
Az írásszakértés alapvetően írás-összehasonlító munka, képzése komplexebb, egyetemi szintű szakmai felkészültséget követel. ${ }^{46}$ Noha a munkát ma már erre a célra fejlesztett szoftverek is segítik, ${ }^{47}$ nem tekinthetünk el a szakértelem és a széles körű tapasztalat szükségességétől. Hírhedt vezetők és bűnözők írásainak elemzése ${ }^{48}$ felhívja a figyelmet a pszichiátriai betegségek kézírásban való tükröződésére. Tehát megállapítható, hogy az egyes pszichiátriai diagnózisok főbb jellemzőinek ismerete elősegíti a hatékonyabb írásszakértői munkát.

Napjainkban államilag elismert írásszakértői oklevelet a Nemzeti Közszolgálati Egyetem 2 éves képzését (Kriminalisztikai Szakértő szakirányú továbbképzési szak) elvégzett és sikeresen levizsgázott hallgatója kaphat, amely stúdium diplomára épül. Ezzel a végzettséggel, meghatározott gyakorlati időt és bizonyos mennyiségú munkát követően válhat valaki kriminalisztikai írásszakértővé. A grafológiai irányzat korábban érettségire épülő (2 éves) OKJ-s képzés keretén belül volt elérhető, de két éve törölték jogosultságát, így manapság csak magánképzőhelyeken tanulható.

\subsection{Dokumentumelemzés, tartalomelemzés és pszicholingvisztika}

A dokumentumelemzés valamennyi nyomozás része. Tág értelemben ebbe tartozik az aktuális nyomozás során készített anyagok vizsgálata, a bủncselekménnyel érintett személyekről korábban készült egészségügyi vagy büntetés-végrehajtásban keletkezett zárójelentések, feljegyzések monitorozása, és bármely, személyiségre utaló, egyéni gondolkodásmódot bemutató írás (például napló) elemzése. Utóbbi (szükebb értelemben véve) a tartalomelemzés. Célja - a releváns bűnjelek megtalálása mellett - az egyéni személyiségjellemzők, a stílus és a motivációs háttér feltérképezése, azok bűncselekményhez kapcsolhatóságának megállapítása. A pszichológiában a tartalomelemzés önálló kutatási módszer. Lényege, hogy a szakember olyan megállapításokhoz jut egy írott anyag vizsgálata során, amelyet a szövegből nem olvashatunk ki. ${ }^{49}$ Módszertanát tekintve létezik tematikus (témakörök előfordulását kutatja), pszichológiai konstruktumú (lelkiállapotra utaló kifejezéseket vizsgál), narratív (történeti koherenciát néz) és nyelvészeti, azaz pszicholingvisztikai (speciális szavak használatát, produkcióját, előfordulási gyakoriságát, kontextusát keresi) tartalomelemzés. ${ }^{50}$

A nyomozásban elsősorban tartalomelemző szoftverek alkalmazása használatos, amelyek alkalmasak a bűnüggyel kapcsolatos releváns, strukturált adathalmaz felállítására, egyéni elkövetői mintázatok létrehozására, bűnözői csoportok közötti kapcsolatok feltárására, valamint veszélyességi faktorok becslésére. ${ }^{51}$ Kérdés azonban, hogy

\footnotetext{
46 Székesi-Katona (2005) i. m.

47 Szijártó Lívia: Az internetes tartalmak elemzése alkalmazott pszichológiai módszerekkel. Hadtudományi Szemle, 9. (2016), 3. 199-207.

48 Innes (2003) i. m.

49 Ehmann Bea: A szöveg mélyén. A pszichológiai tartalomelemzés. Budapest, Új Mandátum, 2002.

50 Innes (2003) i. m.

51 Szijártó (2016) i. m.
} 
a digitális eszközök szolgálhatnak-e a bűnüldözésben megfelelő információval az érzelmek következetes vizsgálata nélkül? Továbbá nem egy pszichiátriai betegség sajátos nyelv- vagy szóhasználatban is megmutatkozik (például autizmus - szóismételgetés, paranoia - gondolattorlódás, gondolatrohanás, skizofrénia - neologizma, új szavak létrehozása stb.), ${ }^{52}$ amely egy egyébként ártalmatlan (de beteg) személy esetében téves figyelemfelhívó jel lehet. Diagnosztikus támpontokkal ezek a szoftverek nem szolgálnak, ennek megállapításához klinikai tapasztalat szükséges. A tartalomelemzést végző szakembereket emiatt érdemes érzékenyíteni az egyes pszichiátriai betegségek felismerésére, amely alapján véleményüket pontosítani tudják.

\subsection{Múszeres vallomás-ellenörzés}

A műszeres vallomás-ellenőrzések közé olyan eljárások tartoznak, mint a poligráf, a hangazonosítás vagy -analízis, a hőkamera, a funkcionális mágnesesrezonanciavizsgálat (fMRI), a monofotó (vagy mermer), illetve némi kompromisszummal a felvételelemzés (ahol az eredmény vagy kiértékelés digitális formában nem jelenik meg). Gyakran tévesen hazugságvizsgálatoknak nevezik, noha az alkalmazott műszerek valójában nem a hazugságot, hanem annak vélt fennállása esetén a stressz okozta, addig tapasztalt „normál” működéstől eltérő testi, fiziológiai jeleket vagy finom agyi hullámokat mérik. A mû́szeres vallomás-ellenőrzés során alkalmazott technikák a hazai gyakorlatban elsősorban megfelelő eszköz- és ügyismeretet, mintsem pszichológiai tudást igényelnek. A hazai joggyakorlatban a műszeres vallomás-ellenőrzés eredményeit - megkérdőjelezhetőségük miatt - szaktanácsadói vélemény keretében kezelik. ${ }^{53}$

Amiatt, hogy a tartósan fennálló pszichiátriai betegségek neurológiai elváltozásokat okoznak (gén-környezet interakciós modell), ${ }^{54}$ a hazugságdetekciós céllal végzett vizsgálatok téves eredményekkel járhatnak. Például a hipochondriás vagy a fel nem ismert skizofrén beteg EEG-je bizonyos, egészséges ember számára szokványos ingerekre felfokozott, amely így fiziológiájára is hasonló kihatással van; vagy a hisztériás beteg reakcióideje eleve megnövekedett értékű, a pszichopatáé pedig lecsökkent az egészséges populációhoz képest. Egy hisztériás beteg továbbá még szuggesztív is, szituációs hatásokra hajlamos változtatni véleményét. Kisagyi sérültek mozgásos viselkedése akadozhat, felgyorsulhat, elnagyolttá válhat, a sérülés típusától függően, amely akaratlanul nyilvánul meg; ezzel szemben a kényszerbetegek szokatlannak tűnő finommozdulatokat tehetnek. Az antiszociális beállítódással együtt jár a vegetatív funkciók alacsonyabb szintű múködése, amely a szorongás minimális szintű megélését eredményezi $^{55}$ (pszichopátiás, antiszociális, nárcisztikus személyek pszichofiziológiai

\footnotetext{
APA (2015). DSM-5 (2015) i. m.

3 Nábrády Mária: A hazugság a mindennapokban. Alkalmazott Pszichológia, 11. (2009), 1-2. 27-54.

4 Tringer László: A pszichiátria tankönyve. Budapest, Semmelweis, 2010.

5 Bagdy Emőke et alii: Az MMPI-próba: elmélet és alkalmazás. Budapest, Akadémiai Kiadó, 1986.
} 
múködése nem minden esetben változik felelősségre vonásuk során). ${ }^{56}$ Tehát egy elkövető hamis állítását, közel sem biztos, hogy jelzi a vallomás-ellenőrző műszer, valamint ártatlan reakciókat értékelhet megtévesztő jelként, amelyek például egy téma iránti szenzitivitás okán is felléphetnek. ${ }^{57} \mathrm{~A}$ vizsgálati eredményt befolyásoló buktatókat egy szaktanácsadóként eljáró pszichológus jó eséllyel képes kiszűrni: például a vizsgálati személy pszichiátriai zavarának gyanúját, megfélemlítés esetén a túlzott feszültségjegyeket vagy éppen azok szokatlan hiányát, nem adekvát mozdulatokat, reakciókat stb. - amely esetek ennél a munkánál is klinikai tapasztalatokat igényelhetnek.

A legkomplexebb és legelterjedtebb technika az említettek közül a poligráf, amely egy olyan sokcsatornás műszer, amely meghatározott kérdésekre a válasz során fellépő, akarattól független élettani változásokat méri (szívműködés, légzés, bőrellenállás, szemmozgás, izomfeszültség, pulzus). Önálló használati jogosultsága megfelelő tanfolyam elvégzéséhez (akkreditált formában a Nemzeti Szakértői és Kutató Központ oktatja) és kezdetben szupervizor melletti múködéshez kötött. Hazai gyakorlatban a vizsgálatot nemcsak pszichológus, hanem bűnügyi tapasztalattal rendelkező, más felsőfokú végzettséggel bíró személy is végezheti. ${ }^{58}$ Alkalmazása a hazai bűnüldözésben elterjedtnek mondható, de sok kétséget hordoz (a bűnügyek csupán 1\%-ában van jelen, és a vizsgálatok csupán 10\%-ában mozdít elő beismerő vallomást), ${ }^{59}$ annak alacsony validitása és reliabiltása miatt (50-95\% között mozog). Így a bírói joggyakorlat közvetett bizonyítékként kezeli, azaz a poligráfos vizsgálati eredményeket nem köteles döntésénél figyelembe venni. ${ }^{60}$

A hangazonosítás (speciális program alapú hanghullám-összehasonlítás) célja annak megállapítása, hogy egy rögzített (akár torzított) felvételen megjelenő hang egyezik-e gyanúsított, tanú, sértett vagy velük kapcsolatban álló személyek hangjával. ${ }^{61} \mathrm{~A}$ hangelemzés emellett a megtévesztés során létrejövő pszichofiziológiai változásokat vizsgálja a meghallgatott beszédében. A rétegzett hangelemző egy szoftver (LVA, Layered Voice Analysis), amely az előadásmódot, a nonverbális jelek hangban történő változását detektálja, ${ }^{62}$ négy személyiségtípust megkülönböztetve: 1. meghamisító (hazug);33 2. elhallgató (információ-visszatartó); ${ }^{64}$ 3. eltitkoló (adott ügyben nem érintett, de

56 Budaházi Árpád: Poligráf. Müszeres vallomásellenőrzés a bûnügyekben. Budapest, NKE szolgáltató Kft., 2014.

57 Hautzinger Zoltán: Az igazságügyi őszinteségvizsgálat. In Korinek László - Kőhalmi László - Herke Csongor (szerk.): Emlékkönyv Irk Albert egyetemi tanár születésének 120. évfordulójára. Pécs, Studia iuridica auctoritate Universitatis Pécs Publicata; Pécsi Tudományegyetem, Állam- és Jogtudományi Kar, 2004b. 43-51.

58 Krispán István: A poligráfos hazugságvizsgálatok rendőrségi alkalmazásának magyarországi múltja, jelene és jövője. Belügyi Szemle, 52. (2004), 6. 42-50.

59 Budaházi Árpád: A műszeres vallomás-ellenőrzés hazai gyakorlata egy empirikus kutatás tükrében. Magyar Rendészet, 19. (2018), 2. 27-43.

60 Budaházi (2014) i. m

61 Innes (2003) i. m.

62 Kis György et alii A megtévesztés tipológiája - összefoglaló tanulmány. Psychologica Hungarica, 4. (2016a), 2. 7-26.

${ }^{63}$ Czabán Csaba et alii: A vallomások igazságtartalmát meghamisítók típusai és vizsgálatuk kihallgatási helyzetben. I. rész: A meghamisító. Psychologica Hungarica, 4. (2016), 2. 27-35.

${ }^{64}$ Czabán Csaba et alii: A vallomások igazságtartalmát meghamisítók típusai és vizsgálatuk kihallgatási helyzetben. II. rész: Az elhallgató. Psychologica Hungarica, 4. (2016b), 2. 36-43. 
piszkos múltú) ${ }^{65}$ és 4. patetikus (magát feladó). ${ }^{66}$ Mivel „egycsatornás” eljárás (csak hangot mér), így még alacsonyabb validitás- és reliabilitásértékekkel rendelkezik, mint a poligráf. ${ }^{67} \mathrm{Az}$ eredmény nem kétséget kizáró, csupán orientáló. Elsajátítása nem kötött végzettséghez, akkreditált képzése nem ismert.

A felvételelemzést a nonverbális jelek megfigyelése céljából szakember (jelen gyakorlatban pszichológus) végzi, ${ }^{68}$ feltételezve, hogy a hazugság által okozott stressz megmutatkozik az előadásmódban, a hangmintázatban, a végtagok (gesztikuláció) és az arc mozgásában (mikromimika vizsgálata), vagy a testhelyzet és a térhasználat megváltoztatásában. ${ }^{69}$ A kutatások az eredményeket a hangelemzésből nyert tipológiákhoz próbálják illeszteni, ekképpen rendszerezni a hazugság egyes gesztusait. ${ }^{70}$ Azonban az előző bekezdésekben ismertetett pszichiátriai betegségek speciális nonverbális megnyilvánulásai két fontos következtetést vetnek fel: 1. a hazugságnak nincsenek univerzális nonverbális jelei (csupán a stressz jegyei észlelhetőek és csak az alapérzelmek kultúrafüggetlenek); ${ }^{71}$ 2. megtévesztő jeleket érzelmileg erősen érintett témákban is produkálhat egy egyébként hazudni nem szándékozó vagy pszichiátriai beteg személy; és fordítva: egy pszichopata akár gyanút eloszlathatóan is nyilatkozhat. ${ }^{72}$ Képzése nem ismert. Úgy tűnik, az eredményes felvételelemző rendelkezik antropológiai (az egyes kultúrák eltérő kommunikációs sajátosságainak ismerete), szociológiai (a társadalmi berendezkedés vagy a hivatás kommunikációt befolyásoló módjai), illetve pszichológiai ismeretekkel is (az egyes pszichiátriai betegségek sajátságos nonverbális megnyilvánulásai nem értelmezhetőek hazugságjelzésként). Jelen gyakorlat alapján a tevékenységet pszichológusok végzik, de - fentebb említettek miatt - egyre inkább körvonalazódik a klinikai tapasztalatok szükségessége.

65 Madzin András et alii: A vallomások igazságtartalmát meghamisítók típusai és vizsgálatuk kihallgatási helyzetben. III. rész: Az eltitkoló. Psychologica Hungarica, 4. (2016a), 2. 44-51.

66 Madzin András et alii: A vallomások igazságtartalmát meghamisítók típusai és vizsgálatuk kihallgatási helyzetben. IV. rész: A patetikus. Psychologica Hungarica, IV. (2016b), 2. 52-59.

67 Budaházi (2014) i. m.

68 Kis György et alii: Újfajta szivárgások leírása a vallomások során, videofelvételek elemzésével. Psychologica Hungarica, 4. (2016b), 2. 60-78.

69 Paul Ekman: Beszédes hazugságok. Budapest, Kelly Kiadó Kft., 2010.

70 Kis et alii (2016b) i. m.

71 Bereczkei Tamás: Az érzelemkifejezések evolúciója. In Evolúciós Pszichológia. Budapest, Osiris Kiadó, 2003. 393-398.

72 Az eljárás használhatóságát illetően a német és francia kutatócsoportok tájékozottabbak, felismerték, például, hogy a félelem és a harag megjelenése az erőszakos elkövetők arcán ritkább, viszont jobban észreveszik áldozataikon, könynyebben felismerik annak jeleit (Wegrzyn-Westphal-Kissler 2017); ugyanakkor ezen elkövetők más érzelmeket nehezebben detektálnak (Schönenberg et alii 2014). Ezek alól a pedofil elkövetők kivételek, akiknek érzelemfelismerése és -produkciója az egészséges populációéval megegyező (Suchy et alii 2009); valamint a pszichopaták, akiknek globálisan gyenge az érzelemfelismerési képességük, mégis, partnerük érzelmi állapotának utánzásával ügyesen kapcsolódnak és alkalmazkodnak (Iria-Barbosa-Paixão 2012).

Catarina Iria - Fernando Barbosa - Rui Paixão: The Identification of Negative Emotions Through a Go/No-Go Task: Comparative research in criminal and non-criminal psychopaths. European Psychologist, 17. (2012), 4. 291-299.

M. Schönenberg et alii: Addressing perceptual insensivity to facial affect in violent offenders: First evidence for the efficacy of a novel implicit training approach. Psychological Medicine, 44. (2014), 5. 1043-1052.

Yana Suchy et alii: Facial and Prosodic Affect Recognition among Pedophilic and Nonphedophilic Criminal Child Molesters. Sexual Abuse: Journal of Research and Treatment, 21. (2009), 1. 93-110.

Martin Wegrzyn - Sina Westphal - Johanna Kissler: In your face: The biased judgement of fear-anger expressions in violent offenders. BMC Psychology, 5. (2017), 1. 16. 
A hőkamerás vizsgálatban testhőmérséklet változásából következtetnek az őszinteség hiányára (felléptekor a testhőmérséklet a homlok közepén, a szemek alatt, valamint a száj és a nyak közepén emelkedik, minimális, $1 / 3{ }^{\circ} \mathrm{C}$-ot). A funkcionális mágnesesrezonancia-vizsgálat (fMRI) kísérletek szerint szintén alkalmas a hazugság tettenérésére (azonban használata jelenleg orvosi kompetenciához és müködéshez kötött). A monofotó vagy mermer (speciális EEG-) vizsgálat a P300-asként ismert agyi hullám felbukkanását méri, ami adott inger emlékképben való tárolását bizonyítja (félrevezető lehet: az információ megléte még nem bizonyítja elkövetést, csak az adattal való kapcsolatba hozhatóságot). Az Egyesült Államokban jelenleg több technika fejlesztése is folyik: a) a Future Attribute Screening Technology (FAST) az arckifejezéseket, a lélegzetvételt és a pupilla tágulását detektálja; b) a Silent Talker technológia során arc- és testmozdulatokat elemeznek; c) a Psychological Stress Evaluator (PSE) pedig az emberi hang stresszhez köthető összetevőit méri, mobiltelefonos alkalmazással; valamint d) szemhőmérőt is tesztelnek már; egyelőre mindegyiket változó eredményességgel. ${ }^{73} \mathrm{Az}$ ismertetett eljárások közül egyedül csak a PSE vizsgázott több kutatásban a poligráfénál is magasabb validitással. ${ }^{74}$

\subsection{Kriminálviktimológia, áldozatvédelem, prevenció}

A kriminálviktimológia a bűncselekmények áldozataival foglalkozik, illetve azzal a kérdéskörrel, amely az áldozatok jellegzetességeit és személyiségvonásait is vizsgálja az áldozattá válás folyamatában, rámutatva ezzel a számukra szükséges segítség (védelem) irányaira (jogi, pszichés, szociális, anyagi). A terület kitér a másodlagos áldozattá válás vizsgálatára is, azaz a büntetőeljárás okozta nehézségek elemzésére, valamint az áldozat hozzátartozóinak vagy a szemtanúk támogatására. A harmadlagos viktimizáció jelenségét is taglalja, amely a média pszichés károsító hatásainak eredményeit méri fel. ${ }^{75}$ Mindez részben analóg a pszichoterápiában használatos iatrogén (szituációból, vizsgálati helyzetből fakadó) ártalom fogalmával. ${ }^{76}$

A viktimológia tudományága így minden mozzanatában összefonódik a pszichológia tudományával, egyrészt az áldozattá válás személyiségtényezőinek kutatásán, másrészt pszichés támogatásukon keresztül. ${ }^{77}$ Mindebből egyenesen következik, hogy a hatékony áldozatvédelem nemcsak bủnügyi tapasztalatot, de pszichológiai ismeretet és gyakorlatot is igényel. Azt, hogy milyen súlyos egy trauma, hogy eléri-e

\footnotetext{
3 Budaházi (2014) i. m.

74 Israel Nachshon - Eitan Elaad - Tuvia Amsel: Validitiy of the Psychological Stress Evaluator: A field study. Journal of Police Science \& Administration, 13. (1987), 4. 275-282.

John Gunn - Gisli Gudjonsson: Using the Psychological Stress Evaluator in conditions of extreme stress. Psychological Medicine, 18. (1988), 1. 235-238.

75 Józsa Zsuzsanna Az áldozattá válás és az áldozatvédelem pszichológiai vonatkozásai. In Csernyikné Dr. Póth Ágnes et alii (szerk.): Kriminálpszichológia. Budapest, Rejtjel, 2006. 233-254.

76 E. Jerry Phares - Timothy J. Trull: A klinikai felmérés. In Perczel Forintos Dóra (szerk.): Klinikai pszichológia. Budapest, Osiris, 2004. 205-388.

77 Popper (2007) i. m.
} 
a poszttraumatikusstressz-szindróma szintjét vagy egyáltalán a klinikai szintet, felismerheti az a segítő is, aki nem pszichológus. Ekkor azonban szakemberhez (pszichiáterhez, klinikai szakpszichológushoz) szükséges fordulni. ${ }^{78}$

\subsection{Börtönpszichológia}

A börtönpszichológia a börtönök világában, a fogvatartottak részére meghatározott és kialakított pszichológusi ellátás. Fogalma szintén nem utal képzettségi szintre, pszichológusi egyetemi diploma meglétét takarja.

Múködési területe igen tág, befogadási vizsgálatokat (újonnan a zárt intézetbe érkezett fogvatartottak pszichés státuszának meghatározását), kockázatelemzéseket (szökési, támadási, alárendelődési, dominánssá válási, öngyilkossági területen), ${ }^{79}$ egyéni és csoportos terápiákat (az azokra való alkalmasság vizsgálatát) és tanácsadás szintű foglalkozásokat, valamint krízisintervenciós és egészségmegőrzési-prevenciós tevékenységet takar. ${ }^{80} \mathrm{~A}$ reszocializáció/reintegráció e munkafolyamatok támogatásával valósul meg. Továbbá a börtönben dolgozó pszichológus egyfajta kapocs is a fogvatartottak és a személyzet között. Munkájával alapjaiban a börtön alap- és biztonsági funkcióját hivatott szolgálni, de olykor a nyomozásban (a fogvatartott személyiségjellemzőinek ismerete miatt) is hasznos segítő lehet. Az eltérő múködési mód okán a közelmúltban születtek olyan elképzelések, amelyek szerint a börtönpszichológiát a kriminálpszichológiától elhatárolva érdemes említeni, ${ }^{81}$ mégis a bűnelkövető személlyel mint a kriminálpszichológia tárgyával történő munkavégzése jogosan a szakterülethez csatolja.

Fentebb felsorolt tevékenységi körök és az elítéltek körében tapasztalható nagyarányú pszichiátriai betegségek megléte jelzi, hogy ezeket a feladatokat hatékonyabban klinikai ismeretekkel rendelkező pszichológusok képesek ellátni. Mindezt pedig a börtön totalitárius rendszere nehezíti, sőt a legtöbbször deficites pszichés fejlődéssel rendelkező bűnelkövetőket még infantilis, kiszolgáltatott állapotukban is tartja, amely nemcsak fokozott szakmai kihívás elé állítja a pszichológust, hanem emberi mivoltát, alkalmazkodóképességét és egészségtudatosságát is próbára teszi.

Phares-Trull (2004) i. m.

16/2014. (XII. 19.) IM rendelet a szabadságveszetés, az elzárás, az előzetes letartóztatás és a rendbírság helyébe lépő elzárás végrehajtásának részletes szabályairól.

80 Marisa Mauro: My Work as a Psychologist in Prison. Psychology Today. 2009.

81 Fliegauf Gergely: A börtönpszichológia elhatárolása a kriminálpszichológiától. Börtönügyi Szemle, 31. (2012), 1. 45-62. 


\subsection{Az állomány támogatása: alkalmasságvizsgálatok, konzultáció, tanácsadás, terápia, mediáció, tréningek, képzések}

Alkalmasságvizsgálatokkal, konzultációs, tanácsadó és terápiás munkával a bűnüldözés során általában a tiszti személyi állomány támogatásának formájában találkozik a pszichológus. Konzultációt az egyetemi végzettséggel rendelkező pszichológus tart, ennek során feladata a problémás életterületek feltérképezése és a személy jellegzetes viselkedési módjainak meghatározása, valamint ezek összefüggéseinek elemzése. Tanácsadást elsősorban tanácsadó szakpszichológus végez, amely lényegében egy rövidebb időtartamú, jelenre fókuszáló, egészséges életvitelt támogató munka. Alappszichoterápiát klinikai szakpszichológusi végzettséggel végezhet pszichológus szakember, amely során a páciens jelen problémáját múltjának bekapcsolásával oldja fel, annak pácienssel való megértetése, elfogadtatása mentén, megtanítva ezzel az egyént újabb, adaptívabb viselkedések alkalmazására. ${ }^{82}$ (A szakpszichoterápia pedig módszerspecifikus elemekkel átszőtt, több éves gyógyító terápiás folyamat.) E formák szưk keretek között valósulnak meg a nyomozás alatt álló személyek esetében, általában burkolt formában, bizalmat kiépítő szándékkal, a bűncselekményt támogató minták, személyiségvonások feltérképezése céljából, míg a terápiás tevékenység elsősorban a börtönben zajló munka keretében használatos. ${ }^{83}$

A mediáció vagy más néven közvetítés célja a konfliktusfeloldás, úgy, hogy az a felek elégedettségét vonja maga után. Ennek során a probléma hátterében álló látens és nyilvánvaló okokat is fel kell deríteni, ahogyan a felek érzelmei és motivációi sem maradhatnak kérdésesek. ${ }^{84} \mathrm{~A}$ munka speciális szakértelmet nem igényel, léteznek mediátori képzések, amelyek kevéssé épülnek felsőoktatási alapdiplomára, emellett pedig tapasztalható, hogy a feladatot legalább olyan jól el tudja látni például egy nyomozó, mint egy pszichológus. Elsősorban nyitott, kommunikatív, kreatív személyiséget igényel a szakterület, valamint az adott ügy pontos ismeretét.

Az állomány részére máig számtalan kommunikációs-pszichológiai jellegű oktatás biztosított. Ezek közül kiemelném az intézkedéstaktikai tréningek hatékonyságát (amelyek alkalmasságot szűrő eljárások is lehetnének), valamint azokat a pszichológiai szakirányú képzéseket, amelyek keretében egyes felnőtt és gyermek pszichiátriai diagnózisok ismertetése történik meg, amelyek konkrét esetbemutatásokkal kézzelfoghatóvá teszik egyrészt a pszichológusi munka mikéntjét, másrészt az egyes kórképek megismerését, kezelését. Önismereti munka szempontjából a csapatépítő tréningek vagy tematikus csoportok kiválóak.

\footnotetext{
2 Bagdy Emőke et alii: Tanácsadás és terápia. Budapest, ELTE Eötvös Kiadó, 2009.

83 Léteznek még ún. alap-pszichoterápiák és szak-pszichoterápiák, előbbi klinikai szakpszichológusi, utóbbi a klinikai szakpszichológusi végzettségre épülő, 2 éves pszichoterápiás tanulmányokon nyugszik. 1997. évi CLIV. tv. 203. §.

84 Farkas Johanna: A büntetőügyekben történő resztoratív igazságszolgáltatás egyik formájának - a mediációnak - pszichológiai vetületei. In Csernyikné Dr. Póth Ágnes et alii (szerk.): Kriminálpszichológia. Budapest, Rejtjel, 2006. 266-287.
} 


\section{A kriminálpszichológusi képzés támpontjai}

\subsection{Szükséges kompetenciák, elvárások, tévhitek}

Láthattuk, a bűnüldözés pszichológusi támogatásában aligha létezik olyan munkatípus, amely ne követelne meg klinikai pszichológiai kompetenciákat (müszeres vallomás-ellenőrzés, mediáció, írásszakértés, dokumentumelemzés). Emellett számos más területen erôsen ajánlott a klinikusi tapasztalat (túsztárgyalás, tanácsadás, áldozatvédelem, kihallgatás, meghallgatás, börtönpszichológia, felvételelemzés, viktimológia), valahol pedig elengedhetetlen (igazságügyi szakértés, terápia, gyermekekkel való munka).

Összességében megállapítható, hogy a bủnüldözésben részt vevő pszichológusnak indokolt lenne rendelkeznie állami és pszichiátriai gondozottakkal végzett, valamint büntetés-végrehajtásban, elitéltekkel folytatott tapasztalattal/gyakorlattal. Munkát könnyítő ismeret még a kisebbségek, szlengek (börtönszlengek) témájában való tájékozottság is, hiszen az eltérő szokásrendszerekből adódó kommunikáció állandó konfliktusforrás. Ennek jobb megértéséhez és kezeléséhez kulturális antropológiai és szociológiai alapismeretek kellenek. (Megtapasztalásához szintén a börtönpszichológiai munka adja a legjobb és egyben a legbiztonságosabb terepet. ${ }^{85}$ Továbbá az önismereti kurzusok vagy szupervízori esetvezetések legalább annyira kulcsai a szakmai sikerességnek, mint a szakirányú stúdiumok. Végül a rendvédelemben dolgozó pszichológus el kell, hogy fogadja a szervezeti érdekek és/vagy az igazságszolgáltatás elsődlegességét a szakmai munkájában, ami a klienssel kötendő teljes körủ titoktartást nem teszi lehetővé.

Megállapítható, hogy a kompetens kriminálpszichológus szakmailag megalapozott elképzelésekkel rendelkezik arról, hogy: a) valakit milyen személyiségbeli tényezők és/ vagy szociológiai helyzetek vezetnek a bünelkövetés útjára; b) milyen információanyag alapján segítsen a bűnüldözésben; valamint c) mely környezeti és személyiségbeli jellemzőkre figyeljen kifejezetten a nyomozás vagy a büntetés-végrehajtás egyes céljainak előmozdítása érdekében. ${ }^{86}$ A pszichológiai módszerek (anamnézis, pszichodiagnosztikai tesztek) önmagukban nem alkalmasak a tényállás megállapítására, de eredményei a hatóságok munkáját és a helyes ítélet meghozatalát segíthetik. ${ }^{87}$ Mindemellett a kapcsolódó jogi és kriminológiai tudásanyag megszerzése alapfeltétele a pszichológusi tevékenység hatósági munkába, megfelelő helyen és időben történő bekapcsolásához.

A (kriminál)pszichológushoz kapcsolódó téves elvárások sokszor bírói szerepbe helyezik a pszichológust, véleményétôl várva a bűnösség megállapítását, holott egyértelmúen „csak” kiegészítő tevékenységet lát el. A pszichológia valamennyi felsőoktatásban alaptantárgy, de ennek keretében sajnos csak híresebb elméleteket tanítanak, amelyek egyes jelenségekre magyarázatot adva, behatárolva mutatják be a szakmát. Emiatt fordulhat elő, hogy többen hiszik, hogy a pszichológus „belelát” mások fejébe, „kitalálja”,

\footnotetext{
Fiáth Titanilla: Börtönkönyv. Kulturális antropológia a rácsok mögött. Budapest, Háttér, 2012.

Popper (2007) i. m.

87 Popper (1970) i. m.
} 
előre megmondja a gondolatait. Ez nem így van. Hasznosabb lenne példákat, eseteket, bủnügyeket, konkrét alkalmazási területeket bemutatni az oktatások keretében, vázolva a (kriminál)pszichológusi munka sokrétűségét, illetve azokat a szakmai elméleti háttereket, amelyeket a munkában alkalmazni szükséges, beleértve a pszichiátriai betegségek sajátosságait is.

\subsection{Egy képzés lehetösége}

Fentebbiek alapján, javasolt a kriminálpszichológusi képzést, a klinikai és mentálhigiéniai szakpszichológusi végzettségre épülő igazságügyi pszichológusi szakértői képzés keretében oktatni, tekintettel arra, hogy annak tananyaga már tartalmazza a szükséges jogi és kriminológiai, ismereteket (a klinikai szakpszichológus képzés pedig pszichiátrián töltött gyakorlatot is nyújt). Emellett a kriminálpszichológusi cím megszerzésének feltétele a rendvédelemben létesített munkaviszony kellene hogy legyen, adott esetben (például rendőri és büntetés-végrehajtási szervek közti átrendeléssel vagy vezényléssel megvalósított) szakmai gyakorlatokkal. Ekként a kriminálpszichológusi cím végzettséget is takarna, magában foglalva a börtönpszichológusi jelzôt is, illeszkedve a Magyar Pszichológiai Társaság keretén belül múködő Kriminálpszichológiai és Igazságügyi Pszichológiai Szekció munkájához.

\section{4. Összefoglalás}

Napjainkban a „kriminálpszichológusok” a rendvédelem területén tevékenykedő pszichológusok, akik elnevezésüket egyelőre önkényesen használják, csak sejtetve bizonyos kompetenciákat, tapasztalatokat, tudástárat.

A tanulmány összefoglalja a rendvédelemben dolgozó pszichológusok sokrétű elméleti és gyakorlati felkészültségét. Hangsúlyozza, hogy a bűnüldöző munkának csak egy része a kriminálpszichológiai elemzés, ami „egy olyan folyamat, amely során számos fontos - akár apró nyom összeillesztésével rajzolódik ki a személyiség teljes képe”.88 Tehát kívánatos, hogy - a kriminálpszichológia definíciójával összhangban - a kriminálpszichológus olyan klinikai szakpszichológus legyen, aki pszichiátriai, bűnüldözési és zárt intézeti munka során szerzett szakmai tapasztalattal, továbbá a rendvédelmi szervek múködési sajátosságainak ismeretével is rendelkezik, emellett eleget tesz szakmai továbbképzési kötelezettségeinek, tudásának frissítése, müködési engedélye és pszichés kiegyensúlyozottságának megtartása érdekében. Ebben persze a munkahelyeknek, a magyar rendvédelmi szerveknek is partnernek kell lenniük. Ekképpen minősülhetne a rendvédelemben dolgozó pszichológus kriminálpszichológussá.

88 Innes (2003) i. m. 201. 


\section{IRODALOMJEGYZÉK}

Adler, Alfred: Emberismeret. Budapest, Göncöl, 1996.

Adler, Alfred: Életünk jelentése. Budapest, Kossuth, 1994.

DSM-5 referencia-kézikönyv a DSM-5 diagnosztikai kritériumaihoz. Budapest, American Psychiatric Association - Oriold és Társai, 2015.

Bagdy Emőke - Pressing Lajos - Bugán Antal - Zétényi Tamás: Az MMPI-próba: elmélet és alkalmazás. Budapest, Akadémiai Kiadó, 1986.

Bagdy Emőke - Buda Béla - K. Németh Margit - Komlósi Piroska - Pintér Gábor - Ritoók Magda - Süle Ferenc - Szőnyi Gábor - Torma Kálmán: Tanácsadás és terápia. Budapest, ELTE. Eötvös Kiadó, 2009.

Bereczkei Tamás: Az érzelemkifejezések evolúciója. In Evolúciós Pszichológia. Budapest, Osiris, 2003. 393-398.

Bereczkei Tamás: Genetikai és evolúciós tényezők a deviáns és a bűnözői viselkedés kialakulásában. Belügyi Szemle, 47. (2004), 6. 21-33.

Bernáth László - Solymosi Katalin (szerk.): Fejlődéslélektani olvasókönyv. Budapest, Tertia, 2001.

Boros János: Jogpszichológia és kriminálpszichológia. Belügyi Szemle, 52. (2004), 6. 5-19.

Boros János - Csetneky László: Börtönpszichológia. Budapest, Rejtjel, 2002.

Budaházi Árpád: Poligráf. Müszeres vallomásellenőrzés a bünügyekben. Budapest, NKE szolgáltató Kft. 2014.

Budaházi Árpád: A műszeres vallomás-ellenőrzés hazai gyakorlata egy empirikus kutatás tükrében. Magyar Rendészet, 19. (2018), 2. 27-43.

Csernyikné Dr. Póth Ágnes: Bevezetés a kriminálpszichológiába. In Csernyikné Dr. Póth Ágnes - Fogarasi Mihály - Kováts Daniella - Józsa Zsuzsanna - Farkas Johanna (szerk.): Kriminálpszichológia. Budapest, Rejtjel, 2006a. 9-24.

Csernyikné Dr. Póth Ágnes: A kihallgatás pszichológiája. In Csernyikné Dr. Póth Ágnes - Fogarasi Mihály - Kováts Daniella - Józsa Zsuzsanna - Farkas Johanna (szerk.): Kriminálpszichológia. Budapest, Rejtjel, 2006b. 171-212.

Csernyikné Dr. Póth Ágnes: A profilalkotás lényege. In Csernyikné Dr. Póth Ágnes - Fogarasi Mihály - Kováts Daniella - Józsa Zsuzsanna - Farkas Johanna (szerk.): Kriminálpszichológia. Budapest, Rejtjel, 2006c. 213-217.

Ehmann Bea: A szöveg mélyén. A pszichológiai tartalomelemzés. Budapest, Új Mandátum, 2002.

Ekman, Paul: Beszédes hazugságok. Budapest, Kelly Kiadó Kft., 2010.

Elek Balázs: A vallomás befolyásolása a büntetőeljárásban. Debrecen, Tóth Könyvkereskedés és Kiadó Kft., 2007.

Farkas Johanna: A büntetőügyekben történő resztoratív igazságszolgáltatás egyik formájának - a mediációnak - pszichológiai vetületei. In Csernyikné Dr. Póth Ágnes - Fogarasi Mihály - Kováts Daniella - Józsa Zsuzsanna - Farkas Johanna (szerk.): Kriminálpszichológia. Budapest, Rejtjel, 2006. 266-287.

Fiáth Titanilla: Börtönkönyv. Kulturális antropológia a rácsok mögött. Budapest, Háttér, 2012.

Fliegauf Gergely: A börtönpszichológia elhatárolása a kriminálpszichológiától. Börtönügyi Szemle, 31. (2012), 1. 45-62.

Gunn, John - Gisli Gudjonsson: Using the Psychological Stress Evaluator in conditions of extreme stress. Psychological Medicine, 18. (1988), 1. 235-238. DOI: https://doi.org/10.1017/ s0033291700002063

Győrffy Ágnes: A túsztárgyalás pszichológiája. Belügyi Szemle, 52. (2004), 6. 66-80.

Hautzinger Zoltán Az igazságügyi kézírásvizsgálat. In Korinek László - Kőhalmi László - Herke Csongor (szerk.): Emlékkönyv Ferencz Zoltán egyetemi adjunktus halálának 20. évfordulójára. Pécs, Studia iuridica auctoritate Universitatis Pécs Publicata; Pécsi Tudományegyetem, Állam- és Jogtudományi Kar, 2004a. 93-100. 
Hautzinger Zoltán: Az igazságügyi őszinteségvizsgálat. In Korinek László - Kőhalmi László - Herke Csongor (szerk.): Emlékkönyv Irk Albert egyetemi tanár születésének 120. évfordulójára. Pécs, Studia iuridica auctoritate Universitatis Pécs Publicata; Pécsi Tudományegyetem, Állam- és Jogtudományi Kar, 2004b. 43-51.

Hobbs, Sue D. - Jenni L. Johnson - Gail S. Goodman - Daniel Bederien-Gardner - Michael J. Lawler - Ivan D. Vargas - Macaria Mendoza: Evaluating eyewitness testimony of children. In Irving B. Weiner - Randy K. Otto (ed.): The Handbook of Forensic Psychology. Hoboken, Wiley, 2014. 561-598.

Innes, Brian: Bünös elmék. Budapest, Skandi-Wald Könyvkiadó Kft., 2003.

Iria, Catarina - Fernando Barbosa - Rui Paixão: The Identification of Negative Emotions Through a Go/No-Go Task: Comparative research in criminal and non-criminal psychopaths. European Psychologist, 17. (2012), 4. 291-299. DOI: https://doi.org/10.1027/1016-9040/a000101

Józsa Zsuzsanna: Az áldozattá válás és az áldozatvédelem pszichológiai vonatkozásai. In Csernyikné Dr. Póth Ágnes - Fogarasi Mihály - Kováts Daniella - Józsa Zsuzsanna - Farkas Johanna (szerk.): Kriminálpszichológia Budapest, Rejtjel, 2006. 233-254.

Székesi István - Katona Ágnes: Az írásszakértés elmélete és gyakorlata. Eger, Országos Írásszakértő Intézet Kft., 2005.

Kertész Imre: A kihallgatási taktika lélektani alapjai. Budapest, Közgazdasági és Jogi Könyvkiadó, 1965.

Kis György - Takács Szabolcs - Liberman Amir - Benczúr Lilla: A megtévesztés tipológiája - összefoglaló tanulmány. Psychologica Hungarica, 4. (2016a), 2. 7-26. DOI: https://doi.org/10.12663/ PSYHUNG.4.2016.2.1

Czabán Csaba - Alpek Alex - Bártfai Anna - Kertesy Andrea - Iványuk Áron - Benczúr Lilla - Takács Szabolcs - Kis György: A vallomások igazságtartalmát meghamisítók típusai és vizsgálatuk kihallgatási helyzetben. I. rész: A meghamisító. Psychologica Hungarica, 4. (2016), 2. 27-35. DOI: https://doi.org/10.12663/PSYHUNG.4.2016.2.2

Czabán Csaba - Alpek Alex - Bártfai Anna - Kertesy Andrea - Iványuk Áron - Benczúr Lilla - Takács Szabolcs - Kis György: A vallomások igazságtartalmát meghamisítók típusai és vizsgálatuk kihallgatási helyzetben. II. rész: Az elhallgató. Psychologica Hungarica, 4. (2016b). 2. 36-43. DOI: https://doi.org/10.12663/PSYHUNG.4.2016.2.3

Madzin András - Alpek Alex - Bártfai Anna - Kertesy Andrea - Iványuk Áron - Benczúr Lilla - Takács Szabolcs - Kis György: A vallomások igazságtartalmát meghamisítók típusai és vizsgálatuk kihallgatási helyzetben. III. rész: Az eltitkoló. Psychologica Hungarica, 4. (2016), 2. 44-51. DOI: https:// doi.org/10.12663/PSYHUNG.4.2016.2.4

Madzin András - Alpek Alex - Bártfai Anna - Kertesy Andrea - Iványuk Áron - Benczúr Lilla - Takács Szabolcs - Kis György: A vallomások igazságtartalmát meghamisítók típusai és vizsgálatuk kihallgatási helyzetben. IV. rész: A patetikus. Psychologica Hungarica, 4. (2016b), 2. 52-59. DOI: https://doi.org/10.12663/PSYHUNG.4.2016.2.5

Kis György - Füzes Nóra - Mátay Gábor - Pusker Máté - Makrai Balázs - Czabán Csaba - Takács Szabolcs Újfajta szivárgások leírása a vallomások során, videofelvételek elemzésével. Psychologica Hungarica, 4. (2016b), 2. 60-78. DOI: https://doi.org/10.12663/PSYHUNG.4.2016.2.6

Kováts Daniella: Elmebetegségek és személyiségzavarok a büncselekmények hátterében. Igazságügyi pszichiátria. In Csernyikné Dr. Póth Ágnes - Fogarasi Mihály - Kováts Daniella - Józsa Zsuzsanna - Farkas Johanna (szerk.): Kriminálpszichológia. Budapest, Rejtjel, 2006. 116-142.

Krispán István: A poligráfos hazugságvizsgálatok rendőrségi alkalmazásának magyarországi múltja, jelene és jövője. Belügyi Szemle, 52. (2004), 6. 42-50.

Lehoczki Ágnes: Nehézségek és módszertani dilemmák a profilalkotás hazai kutatásában. Magyar Rendészet, (2014), 2. 51-61.

Mauro, Marisa: My Work as a Psychologist in Prison. Psychology Today. 2009. Elérhető: www.psychologytoday.com/us/blog/take-all-prisoners/200904/my-work-psychologist-in-prison (A letöltés dátuma: 2020. 12. 03.)

Nachshon, Israel - Eitan Elaad - Tuvia Amsel: Validitiy of the Psychological Stress Evaluator: A field study. Journal of Police Science \& Administration, 13. (1987), 4. 275-282. Elérhető: www. 
amsel-integpro.com/image/users/410209/ftp/my_files/blog/Validity\%20of\%20the\%20PSE. pdf?id=26325260 (A letöltés dátuma: 2019. 08. 09.)

Nagy Vanda: Hazudj, ha tudsz - pszichológus szemmel. 2016. Elérhető: https://mindsetpszichologia. hu/hazudj-ha-tudsz-pszichologus-szemmel (A letöltés dátuma: 2020. 12. 03.)

Nábrády Mária: A hazugság a mindennapokban. Alkalmazott Pszichológia, 11. (2009), 1-2. 27-54.

Pásztor Attila - Mityók Csaba - Németh Ferenc: A rendvédelmi bünügyi pszichológiai tevékenység szakmai protokollja. Elérhető: https://psycho.unideb.hu/munkatarsak/csukonyi_csilla/targyak/ rendvedelempszichologia.pdf (A letöltés dátuma: 2018. 09. 25.)

Phares, E. Jerry - Timothy J. Trull: A klinikai felmérés. In Perczel Forintos Dóra (szerk.): Klinikai pszichológia Budapest, Osiris, 2004. 205-388.

Popper Péter: A kriminális személyiségzavar kialakulása. Budapest, Akadémiai Kiadó, 1970.

Popper Péter: Kriminálpszichológia. In Viant Katalin - Palcsó Mária (szerk.): A rejtőzködő lélek keresése. Budapest, Saxum, 2007. 321-375.

Révész György: Szülői bánásmód - gyermekbántalmazás. Budapest, Új Mandátum, 2004.

Schönenberg, M - S. Christian - A.-K. Gauser - S. V. Mayer - M. Hautzinger - A. Jusyte: Addressing perceptual insensivity to facial affect in violent offenders: First evidence for the efficacy of a novel implicit training approach. Psychological Medicine, 44. (2014), 5. 1043-1052. DOI: https://doi. org/10.1017/s0033291713001517

Suchy, Yana - Wilson Whittaker - Donald Strassberg - Angela Eastvold: Facial and Prosodic Affect Recognition among Pedophilic and Nonphedophilic Criminal Child Molesters. Sexual Abuse: Journal of Research and Treatment, 21. (2009), 1. 93-110. DOI: https://doi.org/10.1177/1079063208326930

Szijártó Lívia: Az internetes tartalmak elemzése alkalmazott pszichológiai módszerekkel. Hadtudományi Szemle, 9. (2016), 3. 199-207.

Tringer László: A pszichiátria tankönyve. Budapest, Semmelweis, 2010.

Vigh András: Az igazságügyi kézírásvizsgálatok aktuális kérdései. Doktori értekezés. Budapest, Eötvös Loránd Tudományegyetem, 2007. Elérhető: www.ajk.elte.hu/file/DI_Vigh_Andras_dis.pdf (A letöltés dátuma: 2020.12. 03.)

Wegrzyn, Martin - Sina Westphal - Johanna Kissler: In your face: The biased judgement of fear-anger expressions in violent offenders. BMC Psychology, 5. (2017), 1. 16. DOI: https://doi.org/10.1186/ s40359-017-0186-z

\section{Jogi források}

2016. évi XXIX. törvény az igazságügyi szakértőkről

2017. évi XC. törvény a büntetőeljárásról

13/2014. (XII. 16.) IM rendelet a kényszergyógykezelés és az ideiglenes kényszergyógykezelés végrehajtásáról, valamint az Igazságügyi Megfigyelő és Elmegyógyító Intézet feladatairól

16/2014. (XII. 19.) IM rendelet a szabadságveszetés, az elzárás, az előzetes letartóztatás és a rendbírság helyébe lépő elzárás végrehajtásának részletes szabályairól

31/2008. (XII. 31.) IRM rendelet az igazságügyi szakértői müködésről

Az Országos Igazságügyi Orvostani Intézet 20. számú módszertani levele: Az igazságügyi pszichológus szakértők müködési köréről és tevékenységéről. Elérhető: https://miszk.hu/files/ 20_modszertani_ level.pdf (A letöltés dátuma: 2018. 11. 13.)

Conference about the question of Domestic Violence 2018. European Association of Police Colleges. Azerbaijan, Annual Conference and Governing Board Meeting, Baku, 2018. 09. 18-19. Elérhető: www. aepc.net/news/ (A letöltés dátuma: 2018. 11. 13.) 


\section{ABSTRACT}

\section{Criminalpsychology and Criminalpsychologist}

Tünde VILICS

The aim of the science of psychology in the field of policing is to promote the law enforcement work of it (clearing up facts, reconstruction of crimes and perpetrators for a more effective prevention), moreover to develop competencies of the staff, in line with the latest scientific results, with the helpful work of criminalpsychologists. The Hungarian Psychology Association has an individual Criminalpsychology and Forensic Psychology Section without special post-graduate education, which means that there is no 'criminalpsychologist' mandate. This study tries to summarise the various tasks of a psychologist who is employed by the police, and suggests an education form and process to fill up with concrete essence the criminalpsychologist status.

Keywords: criminalpsychology, police, lie-detection, personality features, competences, education. 